\title{
Democracy and Governance in the Light of Jürgen Habermas
}

\section{Navarro Ameller JM*}

Bolivian Catholic University and Universidad Mayor de San Simón, Bolivia

*Corresponding author: Prof. Juan Manuel Navarro Ameller, Doctor of Law from the UANL Mx Monterrey, Professor at the Bolivian Catholic University and professor at the Universidad Mayor de San Simón, Bolivia, Email: amellernavarro@gmail.com

\section{Research article}

Volume 4 Issue 4

Received Date: November 16, 2021

Published Date: December 17, 2021

DOI: $10.23880 /$ phij-16000208

“... The political parties' struggle for power lacks any valid dimension (...). In democracy it is not a question of ascertaining the objective truth of the political parties, rather what matters is creating conditions for the democratic acceptance (...) of a society that would have to democratically administer itself"

\section{Abstract}

The purpose of this article is to examine how deliberative politics and discursive construction are understood in the light of Habermas. The fundamentals presented try to show a reflection based on a philosophical position applicable to the different political behaviors in a plot of power play in specific cases.

Keywords: Deliberative politics; Governance; Power games

\section{Introduction}

It is necessary to reflect on one of the topics that Habermas supports about liberal politics, which was built on the basis of a liberal philosophy, as opposed to French philosophy with Lyotard, Foucault and Deleuze, who put aside liberal politics by clinging to a philosophy, modern universalist. It is because of this abandonment of demoliberal ideals that Habermas criticizes them, on the one hand, as attached to a mere context-dependent social criticism, and on the other hand, as neoconservatives, an aspect that we will explain later.

Habermas tries to revalue philosophy and for this he resorts to Kant and Hegel, which leads him to disregard those apologies for the "end of philosophy" as he himself has called them, among which he ascribes to the French thinkers just mentioned, as well as T. Adorno and M. Heidegger.
Finally, it is a question of giving a solution based on the foundations of Thomas Kuhn regarding the proliferation of competing articulations, the willingness to try everything, the expression of explicit discontent, the recourse to philosophy and the debate of the fundamentals "they are the characteristics of the transitions of intellectual paradigms. We are, then, before a transition of paradigms.

Once returning to Kantian and Hegelian thought, those who accept the basic characteristics of modernity, seeking unification, Habermas takes up Hegelian philosophy to start anew, in order to avoid disillusionment with the "philosophy of subjectivity."

In this way, the philosophical reflection focuses on democracy and governability in the light of Jürgen Habermas, entering into an analysis of the power games that materialize in political activity.

${ }^{1}$ Vid. Facticidad y Validez, Ed. Trotta, pp. 370, 63-64, Jürgen HABERMAS, nació el 18 de julio de 1929 en Dusseldorf, Alemania, estudio filosofía, psicología, literatura alemana y economía en las Universidades de Zurich, Gotinga y Bon. Ejerció como profesor en la Universidad de Heidelberg y Francfort en las materias de filosofía y sociología. Recibió muchos premios a nivel internacional, Doctor Honoris causa, titulo otorgado por varias Universidades a nivel mundial 


\section{Philosophy International Journal}

\section{Methodology and Techniques}

This article starts from the following question: Can the foundations of Jürgen Habermas be applied in the field of governance and democracy? In this regard, it has been proposed to have the objective; apply the fundamentals of democracy and governance in the philosophical light of Jürgen Habermas.

The methodology used is analytical and deductive, which will allow us to arrive from general aspects related to governance to particular situations such as power games. On the other hand, the analytical method will make it possible to decompose governance and the materialization of democracy into its most essential elements.

\section{Development}

\section{Entering a procedural concept of democracy}

One of the best works of Jürgen Habermas is "Facticity and Validity" According to Habermas, men have freely and autonomously created norms such as social mediation so that they are freely applied to them. However, from reality, social power and political actors, in the face of the rule of law, create constant tensions and conflicts which are manifested in governability vs ungovernability.

Habermas, argues that the application of law and logically in the administration of public administration in general, reason litigates against itself, which leads us to think that there is a debate on the rationality of philosophy. Habermas affirms: "The critique of reason is also the work of reason"

Habermas [1], thereby indicating that the philosophical foundations of modernity and post-modernity continue to be debated.

Habermas tries to give a new impulse to philosophy and for this he resorts to Kant and Hegel, which leads him to disregard those apologies for the "end of philosophy" as he himself has called them, among which he ascribes to the French thinkers but, it is necessary to carry out the following questioning; Is a return to philosophy necessary in this era where apparently social tensions and conflicts are being solved with democratically elected governments?; The answer can be found in Thomas Kuhn and J. Rawls: the proliferation of articulations in needs for primary goods, the expression of explicit discontent, are the characteristics of the transitions of intellectual paradigms (Rawls, 1997). So we are faced with a paradigm transition and the philosophical explanations applicable to different political responses are still valid.
Habermas, taking up part of Kantian and Hegelian thought, considers that he is looking for a rational unification arising from the separations produced by the principle of subjectivity, something that the philosopher ignored in the "critique of pure reason [2]." Habermas, takes up the Hegelian philosophy to avoid in this way the disillusionment with respect to the "philosophy of subjectivity"

It is for this reason that Habemas emphasizes the communicative reason or communication community, thus correcting the Hegelian error in the text "Facticity and validity", on the other hand, the breaking of the social mediation that exists in governance occurs as a consequence that modern societies have become complex, and that, as a consequence of this, the average society only in a centralist government finds it difficult to absolve its needs of different kinds [1]. This implies entering the new paradigm "Paradigm of complexity within governance".

\section{The paradigm of complexity and Habermas's vision}

Before entering Habermas's central position, it is necessary to briefly analyze what could be understood as the Paradigm of complexity and its relationship with the power that a certain government manages, since there is an indissoluble element with what Habermas describes "Deliberative Politics "

Etymologically paradigm comes from the Greek paradijma which means, model or pattern of some object or subject of study, a definition in Latu sensu proposed by Joel BARKER describes that the paradigm is; "A series of rules and regulations with which we can establish limits and provide formulas with which to successfully solve problems within certain limits", as described by the same author, paradigms act as filters that allow us to select data and experiences of a given phenomenon. For Salvador PÁNIKER a paradigm is: "A set of theories or dominant traits of the same shared by the scientific community at a certain time" (Pániker, 1989).

According to this position, it is necessary to emphasize that in a general framework a paradigm confers on us the study of a series of known phenomena where the community of thinkers and politicians is subject to a series of aspects about how the demands of society would materialize, and logically this aspect does not escape its application as regards deliberative politics. In this way, principles that govern the life of a paradigm are being consolidated, not in vain several authors who study the subject describe that: "These principles and assumptions determine the way in which people live and act. All these assumptions are called Paradigms" (Stover, 1996). 


\section{Philosophy International Journal}

Within the analysis of the State, there are currently certain Paradigms such as the way to carry out the administration about the government, but this way of carrying out the departmental government that to some extent could be paralyzed without giving rise to a new optimal paradigm to the that we could call the governance paradigm and that should be legally and legitimately permeated by the different social sectors in order to satisfy their most basic needs.

Complementing this, Jacques ORDINO maintains that "the whole is different from the sum of the parts", so the whole must be studied in its complexity as the State and the government being the whole, it must be applied in all its parts, from a static dimension to a dynamic dimension, from repetition to change, from order and its disorder, from invariance to innovation, from reproduction to involution, from the subject that is projected towards society, from the determinism in decision-making to the freedom to make them, from normal autonomy to extraterritoriality in relation to the State, from its harmony to discord, from myth to reality and from the of be in accordance with the laws and mechanisms of the Democratic exercise in Bolivia and, on the other hand, the solution cannot go against the valid morality widely accepted in society.

It is also important to mention that in the ancient currents of law, they understood the formalist concept of the state before the concept of the modern welfare state. The formal ideology of the rule of law is made up of the following elements:

The first is the one referred to the separation of powers, legislative, executive and judicial in order to avoid a centralism of power and possible abuses of it.

1. Legislative ex ante that regulates the pre-established power with transparency and clarity, which does not happen, for example, in Bolivia where corruption rates are high.

2. The powers must be independent, precisely to avoid political interference and abuses of power.

In the case of Bolivia, this division of powers is divided into; the executive body, legislative body, judicial and electoral body [3].

On the other hand, in the case of the executive body that has the function of administering the government and the power conferred in recent decades, it has shown a series of weaknesses in its administration, which results in widespread discontent and consequently ungovernability. For its part, the legislative body has more often than not been fragmented, which makes it impossible to consolidate consensus to enact laws aimed at regulating different aspects. On the other hand, the lack of consensus and in a Dictatorial
State, makes laws of different kinds be drawn up, which are destined to benefit some sectors of the population, which makes possible the "rebound" reaction of the sectors that are They are at a disadvantage and consequently the figure of social crisis and ungovernability appears again.

All these aspects make the government, once consolidated, become weak as a consequence "ex post" due to the "ex ante" promises of the elections that brought it to power.

The second refers to the existence of a legal professionalism in charge of questions of law, which is not a reason for analysis of this work, the third element refers to the idea of legal protection that becomes the center of the state where citizens. They protect themselves from abuses by other citizens and the State, which does not exist in a Dictatorial Government. The fourth and fifth elements make mention of procedural legal principles such as the principle of legality and that of the prohibition of Refortio in peius, and an adequate structure of legal norms and principles that are used as an umbrella of protection, which in Dictatorial governments do not exist fully either.

As can be seen, the welfare state seeks a counter position to a Dictatorial State, to consolidate a minimum social security "good life", having as a guarantee a good application of justice by the rulers, however, in some countries such as Finland the welfare state is exercised on many occasions by people who are not trained in law such as administrators, economists, sociologists, political scientists, etc.

The characteristic of the welfare state that Bolivia must achieve in terms of its normative structure is that some norms such as those in the field of social assistance must be defined as goals, giving rise to open norms, mechanisms and policies that try to give adequate legal protection to society [4], this position has given rise to the dilemma of modern law together with the tendency of the materialization of certain ideas such as formality and reasonableness.

Due to the above described, the future needs of the welfare state, legal reasoning faces a series of situations and demands of the formal state such as being; the new standards of rational and communicative legal discourse. The new discussion about the substantive criteria for reasonable decisions where Law and Morals will be much more in-depth.

\section{Habermas communication systems and procedures in governance}

Habermas describes that the State constitutes a subsystem among other functionally specified social 
subsystems. These maintain system-environment relationships with each other in a similar way to how people and their society do; however, reality often shows us that systems theory erases the connection with the normative contents of practical reason.

This may be due to the fact that communicative rationality does not have to be understood as the classic form of practical reason, that is, a source of norms of action since the norm has a normative content to the extent that whoever acts communicatively has no choice but to assume budgets of businessmen, workers, unions, public and private entities in protest of the 2020 elections.

\section{The rulers' power play}

In order to understand Habermas when he refers to the rules of the game [5], it is necessary to explain which are the power games that exist and that from our point of view there are several. For this purpose, I will use the description of the previous forms of power analyzed in the lines before this text. The games are interspersed by a series of forms of relationship that go from the interior of government programs to the great layers of control over society and are often projected into the interior of social groups and political parties with the purpose of acquiring hegemonic dominance and control of the government, always backed by one or several political parties that are in the Legislative Assembly.

Although Habermas does not use the name "Power Games" for the dominance of power to occur, there must be a series of games, which I will call "Power Games." In this way, government policies and social demands obey a series of games that are carried out in different ways and in certain cases through the exercise of the vote destined to elect the President of the Republic, deputies and senators, for example, the avatars of the candidates when they play to win hierarchical positions, implies a set of relationships and multiple positions originating from the social and political sectors. Next, I will describe the different games that take place in Bolivia and that wear down democracy.

\section{The insubordination game}

It materializes with resistance to the authority established in the governing body, which ranges from protest to rebellion. The explanation of this game originates because no one accepts their subordinate status as a natural condition and when social actors are faced with a democratic process, those who even resist voting, the game materializes with protests, posters that question the suitability of the candidates and even allegations of corruption and mismanagement of money by government officials, who more often than not prove said accusations and in others, it is very difficult to prove them because they have the backing of the national hierarchical bodies, on the other hand, in the case of Bolivia, insubordination is manifested by the isolated comments of the government officials themselves questioning the way in which government policies are carried out. The cases are obvious and there are several events recorded, for example, we have the insubordination game registered in the government of Gonzalo Sánchez de Lozada in the so-called "Black October" or the recent case of 10/22/2019 where the Civic Committee Pro Santa Cruz declares indefinite Civic Strike, and the Departments of Cochabamba, La Paz, Chuquisaca, Tarija, Oruro and Beni join this measure, with the apparent majority support of businessmen, workers, unions, public and private entities in protest of the 2020 elections.

\section{The game of counterattack}

This game is played by those who have the legally established power, those who attack their adversaries, although in the Bolivian reality there have been many cases of counter-attack from spheres outside the context of government, I am referring properly to the interference of political parties that They did not obtain a majority and they could not obtain deputies or senators, this game materializes in blackmail, threats of accusations of corruption, which at a certain moment will fulfil its objective, that of softening the opposition in the rest of the way.

However, the counterattack game is the daily bread in Bolivia and it only remains to wait for the opponents the best moment to carry out their attacks at the propitious moment that changes the decisions of government policies because the counterattack many times it is better than government policies.

\section{The sponsorship game}

This power game consists of playing to create sustenance of power using those who are in the spheres of the legislature, the executive or vice versa. In any case, the one who wishes to be sponsored adheres (like a shadow) to the one who has the hegemony of power or manages social masses professing their loyalty in exchange for power. In this way, the position of Vice President enjoys the patronage of the president, the position of minister enjoys the patronage of the president, the Deputy and Senator, enjoys the patronage of the head of the Party and so on, the small party enjoys the endorsement of the large party and all are waiting for a legacy of inheritance that must complete life cycles until all benefit from what they want. The same happens with social groups or unions that in the Bolivian case the Central Obrera, the federations of the tropic of Cochabamba support the current government elected in 2020 . 
However, the sponsorship game can expose the fragility of the executive as well as the Legislative, these cases refer, for example, to the sponsorships carried out by the rulers and who expect congressional support, however, in the face of misintelligence among them, the only thing they show it is its progressive weakening and the lack of credibility in Bolivian society.

\section{The game of alliances}

This game is played between more or less equal political parties, who agree to mutual support to form a power base. This type of game is carried out at higher, intermediate, middle and lower levels, these through alliances can pass from one level to another, and many times they were projected at levels outside the government, that is, towards unions or social groups, which thanks to the Alliances that permeate the layers of the State Government, will have the guarantee of being part of the power structure within the government structure. On the other hand, the game of alliances permeates the international context when there are alliances of presidents of different states who more or less have the same political inclination or at least the same discourse. This is the recent case, for example, of two political parties Comunidad Ciudadana and BELIEVE that they become allies as opponents of MAS IPSP.

\section{The empire building game}

The game within the executive and the legislature is consolidated with the construction of the empire, in my opinion to win this game all the games described must have been exhausted and won. However, it is not necessary to be in a government function to build the empire since thanks to the alliances that exist in spheres of the State Government, and in different government strata, there are still some "Mohicans" of old party data, who will return when the flows of his political life have ended in other places, or change the political party that still holds power, of course, while his political life is in force and enjoys the power of the State Government, this power will put at the service of the Head of Government or of his Party Leader fulfilling the alliance with any of the Government decision levels. In this way, the construction of the empire will reign surviving several elections, as happened with the MIR revolutionary nationalist movement, which has been in the government of Hugo Banzer Suárez on two occasions, and in the government of Gonzalo Sánchez de Losada or the government of Evo Morales Aima who had in his ranks former supporters of other political parties who are now from the Movement for Socialism and who were in office for three consecutive periods. Currently, the government of Luis Arce who was elected as a presidential candidate by the Movement for Socialism in the 2020 general elections, who won in the first round with $55.1 \%$ of the votes, to this and under the so-called game of power, it remains to build your political empire.

\section{The game of budgeting and wealth distribution}

It consists of being able to prepare a budget "General Budget of the Nation" to comply with the obligations towards Bolivian society, however, in some circumstances this budget preparation is tricky due to international commitments with the World Bank and the IMF, they do not allow a Adequate distribution of wealth for the people, despite all the difficulties, the rulers try to show the best living conditions that a certain country has and, contradictorily, the needs of society are not consolidated.

On the other hand, the distribution of wealth is often diluted due to improper management of it and is often lost when entering the circle of corruption, as for example in Bolivia in 2019 and 2020 it was the case of buying riot gear among other acts. Due to this and also thanks to the budget, certain decision-making sectors can benefit from "certain salary increases" or, where appropriate, the so-called loyalty bonuses, which have caused the lack of credibility of society towards the executive body.

Apart from this situation and in a state of health emergency "pandemic", Bolivia has not been successful in obtaining external financing to improve the economic crisis, which could worsen rapidly, because the reserves of the Central Bank of Bolivia cannot sustain indefinitely the health crisis and that will affect to a greater or lesser extent the distribution of wealth.

\section{The game of expertise}

It consists of the use of all the skills that government officials have at their disposal in order to take power, this implies prior agreements, loyal and unfair attitudes, counterattacks, and tactics developed in the good style of "civilized warlike" confrontations. , which consists of the use of knowledge and skills not officially recognized to create a power base, either by showing them off, or by pretending to possess them. The fact that these skills are not officially recognized does not mean that they are not openly known, where in the case of authoritarian governments, such as Gonzalo Sánchez de Lozada, or Evo Morales Aima, who has handled his call very well "Social control" or "consultation of the masses." The game of expertise is developed with all the techniques and tactics directed by generals and captains of different decision-making levels and that in some cases "divers" are a useful human resource in decision-making, this is what it is also known as the puff game. On the other hand, social movements also show their abilities by stating, for example, that indefinite strikes will be developed blocking roads if Decrees are not repealed or the percentages of the fruits of non-renewable resources are improved, such as gas or electricity. approval of the New Bolivian Constitution by the Constituent Assembly, which has said of the latter the socalled "red pochos" were present in the city of Sucre, pressing 


\section{Philosophy International Journal}

for the approval of the New Constitution.

\section{The game of despotism}

The despot is the boss, the sovereign who governs arbitrarily, the word comes from the eighteenth century, whose actions were developed under the premise "Everything for the people, but without the people", in short, the despot is the one who abuses the power arbitrarily. What happens is that within this meaning it seeks to consolidate a hierarchical position using "tyrannically" the power that he legitimately holds with those who do not have it and who have less power, consequently making the life of society "a nightmare". In the Bolivian context, despotic governments have been, for example, in the dictatorial era Hugo Banzer Suárez, in the democratic era Gózalo Sánchez de Lozada, which devastated the people of El Alto, causing several deaths in the sectors, the phrase after the war massacre gas was eloquent "hopefully with this lesson we will begin to live in peace" shows the tyranny and despotism of the government that was democratically elected but misused the power that was conferred on it, because of this the people as a whole developed the game of expertise and strategic alliances blocking the country and calling for the resignation of the President of the Republic, which occurred in October 2003. Apparently in this episode the game of despotism was defeated by the fire of the expertise and strategic alliances developed by social sectors. In the same way, the government of Evo Morales and Álvaro García Linera, which in function of government and according to some sectors of society call them despots due to the totalitarian politics they show, this power game was evidenced with many wounded and killed.

\section{The game of the rowdy masses}

According to this game is where there is more at "stake", due to what is sought, a change in policy resisting compliance and rejecting the government's measures, however there are those who fight intermingled with these groups to take authority legally constituted, and therefore seeks to bring down the legally constituted power, this becomes a dangerous trigger which could be the cause of the resignation of the President in which although the spearhead is certain social groups, the catalysts of the The product is the sectors of other groups supported by political parties that are in the opposition.

It is important to point out that the good game of the riotous masses should not be confused by the legitimacy that is given or not by a whole people who at a certain moment delegated power to the first President.

However, from what has been previously described and following Habermas, it is unquestionable that the party in power will never restrict the political activity of citizens or parties as long as they do not undertake the attempt to overthrow the government through violence. Parties that have lost elections never try to prevent, through violence or any other illegal means, the winning party from taking office. Under these conditions a peaceful turn in power is assured.

The rules of a democracy characterized by competition between parties, which derives its legitimacy from the majority vote obtained in free, equal and secret elections, gain plausibility from a specifically modern understanding of themselves and the world and it is the same individuals who They voluntarily give normative validity, through the act of their free assent. This voluntarist understanding of validity responds to a positivist understanding of law: as law is considered that and only that which a political legislator, elected according to established criteria, in law.

Now, when those affected, from the perspective of the participants, want to make this explanation their own, they certainly fall into the temptation to seek foundations for ethical subjectivism, either in supra-positive human rights, or with the help of a point of view. moral, articulated in deontological terms, according to which only what everyone could want would be valid. On the other hand, and according to the assumptions of ethical subjectivism all have equal power, the majority of votes are, at least an impressive numerical expression of the superiority of force even for the minority:

"But if you look at things from this perspective, then this justification of the democratic procedure is nourished by the threat of the majority to break the agreement on the renunciation of violence if things are not done as they want... Democracy does not mean, according to this, but rather that a part of the people dominates for a time according to this, but rather a part of the people dominates for a time over the other ". When this socio-psychological effect of intimidation, which is threatened by a numerically stronger or at least symbolically stronger party, is viewed against the background of the latent danger of a civil war, then temporally limited domination of the majority it is offered as an "acceptable solution to the problem of power [1]."

The majorities in favor of such guarantees of minority interests are explained by the fear of the majority in each case of becoming a minority in turn. The danger of a perpetuation of tyrannical majorities is prevented and avoided because the majority, for fear of losing their power, and the minority, due to the prospect of a rotation in power, would be motivated to abide by the established rules of the game. Where the production and obtaining of legitimation comes to an end and consists, then, in an integration of means of "ideological politics" and means of "social policy", but it has needed an ideologically convincing interpretation. 


\section{Political Parties}

Within the explanation of social movements, the theory of collective behavior refers to the interactionist approach [6], which responds to a pluralist conception of society where it is very difficult to channel their expectations and demands through political institutions. As a consequence, the nexus of the political parties that serves as a bridge between society and the government through Congress is negative, especially if the social sectors are not fully represented in it [7-14].

However, the lack of credibility in the democratic system in the Bolivian case and the lack of governance has been due to the fact that there is no real and effective participation of the citizens, this leads to a crisis in representativeness since the population.

\section{Discussion}

Habermas's position shows logic of a proceduralist that may not necessarily occur in a society that has a short democratic life, it is for this reason that to explain Habermas's position it is necessary to incorporate power games to apply them to specific cases.

\section{Conclusions}

Habermas arrives at a relatively positive evaluation of the possibilities of a deliberative politics, based on the historical-legal reconstruction of the constitution-granting processes.

The results of a deliberative policy can be understood as communicatively generated power, which enters into competition with actors who threaten to acquire a potential for social power, on the one hand, and with the administrative power of the officials who hold it". With this, however, it is not clear whether such optimism is also valid for the present. Habermas opposes concepts of systems theory, which want to understand democratic institutions only as the supervision of intersystemic negotiations, insofar as he degrades them as a renewal of the Hegelian class state. Such a conception not only considers it (descriptively) unsuitable to offer global social integration benefits. He also insists (normatively) that the relations of the state administration with corporate negotiators must remain asymmetrical, so that the will of the citizens formulated legislatively prevails. "Only in this way is the connection with the public of the citizens ensured."

According to Habermas, the latter "peripheral structures" as an opinion formation process can be expected to perceive "global social problems, interpret them and put them on the scene in an innovative way and, in turn, attract attention". These "peripheral structures" are analyzed in more detail below under the keywords "public space and civil society". The public space is described as an open network of opinions, which are formulated in natural language. In public space, influence is formed and fought for, ideally deciding the authority of the public. Civil society transmits the problematic social situations perceived in the vital world to the political public space; its nucleus is the non-state associative entity. In this regard, Habermas thinks especially of the new social movements, to which he recognizes as a principle a greater sensitivity to the essential problematic situations of recent decades (from the arms race through the risks of the peaceful use of atomic energy, genetic research, even feminism, which in the Bolivian case could be understood as the social movements supported by Evo Morales Aima and the Movement for Socialism. The budget for its effectiveness is the constitutional protection of privacy, which is clarified in the opposite framework of socialist state societies totalitarian.

Deliberative politics is based on an "interaction between a public space based on civil society and the formation of opinion and will in the institutionalized parliamentary complex in terms of a rule of law", and with respect to which the actors in the space The public must exert influence, but not power. Habermas does not close, however, to the question, if civil society and public space are not exposed to abuse by the power of the media or populist political movements.

\section{References}

1. Habermas J (1990) Facticity and validity. Valladolid: Simancas S.A.

2. Kant I (2021) The Best 15 Books of Immanuel Kant.

3. Bolivia (2009) State Constitution. La Paz: Official Gazette.

4. Aarnio A (1990) Rationality and Social Communication Law. As.Bs: BEFD.

5. Navarro Ameller JM (2006) Representative and participatory democracy in Bolivia "Ungovernability". Mountain.

6. Larraña E (1999) The construction of social movements. Madrd.

7. Acosta AM (2000) Government and Governance. Mexico: UNAM.

8. Alf R (1989) Why Democracy? Madrid: Center for constitutional studies.

9. Cohen J (1989) Deliberation and Democratic Legitimacy. In: Matravers D, Pike JE (Eds.), Debates in Contemporary Political Philosophy: An Anthology. Routledge, in 
Association with the Open University.

10. Cohen J (1999) Deliberation and Democratic Legitimacy. Mexico: Oxford.

11. Dewey J (2001) The Public and its Problems. Chicago.

12. Ibarr E (2001) The dilemmas of the institutions. Mexico:
UNAM.

13. Ibarra ER (2021) Idea and Criticisms.

14. Iriarte G (2003) Training in the values of Democracy. Cochabamba: Kipus. 